\title{
Analysis of Cow Hide Glue Binder in Traditional Dancheong by Enzyme-linked Immunosorbent Assay
}

\author{
Jia Yu', Yong Jae Chung ${ }^{2, *}$ \\ ${ }^{1}$ Institute of Preservation Conservation of Cultural Properties, Korea National University of Cultural Heritage, Buyeo 33115, Korea \\ ${ }^{2}$ Department of Heritage Conservation and Restoration, Graduate School of Cultural Heritage, Korea National University of Cultural \\ Heritage, Buyeo 33115, Korea
}

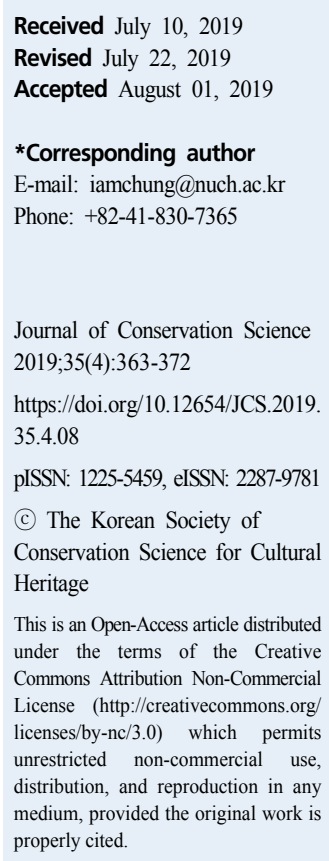

ABSTRACT Animal glue has been used as a binder in Dancheong since the Joseon dynasty. Binders play an important role in determining the physical characteristics of a painting layer. The analysis of binders can be used to identify the materials and techniques used in traditional Dancheong. Binders can be investigated using physicochemical component analyses methods such as gas chromatography/ mass spectrometry, pyrolysis-gas chromatography/mass spectrometry, and fourier transform infrared spectroscopy, but the detection characteristics vary depending on the degradation properties of the pigment and binder. Therefore, cross-validation using a combination of physicochemical analysis and enzyme immunoassay is used to increase the reliability of the results. In this study, we present an enzyme-linked immunosorbent assay (ELISA) as an example of an enzyme immunoassay as a method for analyzing animal glue, a traditional binder used in Korea. The applicability of ELISA was tested using commercial animal glue, in addition to animal glue produced using a variety of extraction conditions. The animal glue was analyzed in a Noerok-additionally coated-replica sample to evaluate the possibility of analyzing the animal glue in a paint layer mixed with pigment. Based on the results, we performed an assay on the use of animal glue in the Dancheong sample of the temples of the Joseon dynasty, that are estimated to have been built in the $17^{\text {th }}$ century.

Key Words Dancheong, Binder, Animal glue, Enzyme-linked immunosorbent assay (ELISA)

\section{INTRODUCTION}

Dancheong is a traditional technique for expressing the hierarchical order of buildings and for protecting and decorating the wood surfaces. In Dancheong, wood is used as background material, pigments for coloring, and binders for the adhesion of powdered pigments to the wood's surface (Kim et al., 2014). Animal glue was mainly used in Korean Dancheong binder, which is a kind of gelatin obtained via hot-water extraction of animal hide collagen. Animal glue has been used from the days of the Joseon dynasty, but given that acrylic emulsion which is a synthetic binder was developed in the 1970s, subsequently, this binder has been primarily used. According to the records in the Uigwe(The royal protocols of Joseon dynasty) such as "Changgyeonggung Palace Suri Dogam Uigwe" and "Gwanghaegun Sachin Chusung Dogam Uigwe", the Dancheong binder in the Joseon dynasty made use of various organic materials such as starch paste, beeswax, lacquer and drying oil, in addition to animal glue(Koo, 2016).

Although the binder is an important factor that affects the physical characteristics and durability of the Dancheong painting film, there are limited studies on the analysis of traditional binders in Korea. In 2015, Jong Seo Park established the feasibility of the analysis of these binders by 
presenting pyrolysis products of various types of animal glue using pyrolysis-gas chromatography/mass spectrometry (Py-GC/MS)(Park, 2015). Subsequent to the report, replica samples of Dancheong were fabricated using animal glue, drying oil and acrylic emulsion, and Py-GC/MS and Fourier transform-infrared spectroscopy (FT-IR) were used to determine identification factor. In the process, it was established that Py-GC/MS is a reliable method for analyzing animal glue(Park et al., 2016). In other countries, several studies have reported on the investigation of a variety of binders including plant gum, animal glue, and egg white, using GC-MS, Py-GC/MS, and FT-IR, in addition to principal component analysis. Results based on statistical analyses have also been reported(Colombini and Modugno, 2004).

The identification of animal and plant binders is possible using Py-GC/MS or FT-IR, but it is difficult to classify animal species based on only this kind of component analysis. In addition, cross-validation using a variety of assay methods is required because many different results can be obtained depending on the mixed pigment or the state of degradation. In this regard, many studies have been conducted to identify binders using enzyme-linked immunosorbent assay (ELISA) based on antigen-antibody reaction. ELISA is a quantitative analysis technique in which the analyte acts as the antigen and an enzyme is combined with an antibody to react with the antigen. The assay method was developed for the diagnosis of diseases and for clinical applications. It has been widely used in the fields of medicine, agricultural crops, and livestock. The technique can increase the sensitivity of a reaction by combing an isotope, a fluorescent substance, an enzyme, etc. with an antibody, which facilitates the identification of a sample containing the minimum amount of analyte.

In addition, extra equipment is not required apart from a microplate reader to measure absorbance. Another advantage of this approach is that it does not require a long assay time. Mazurek et al. (2008) proposed an antibody and an experimental method to analyze a variety of binders such as plant gum, animal glue, egg white, and fish glue of painting layers using ELISA(Mazurek et al., 2008). In China, Hu et al. (2012) used ELISA and immunofluorescence microscopy (IFM) to identify various binders related to animal glue, casein and fish glue in Chinese mural paintings from the $3^{\text {rd }}$ to $5^{\text {th }}$ century. Moreover, the results from quantitative analysis of the effect of mineral pigments on the denaturation of protein binders such as casein using ELISA have been reported(Ren et al., 2016).

Binders in a painting layer mixed with inorganic pigments are affected by the metal ions of the mixed pigments or undergo denaturation due to various degradation factors. As such, it is difficult to identify binders using only physicochemical component analysis. Therefore, ELISA as well as GC/MS and Py-GC/MS, are required for a more comprehensive investigation of traditional painting techniques. In this regard, this study examines the applicability of ELISA for Dancheong binder analysis based on various types of animal glues used in Korea and the Danchung samples, which are replicas of Noerok-additionally coated-Danchung. Moreover based on this investigation, we examined animal glue, an animal binder used in traditional Dancheong by applying to the technique to samples in temples of the Joseon dynasty in the $17^{\text {th }}$ and $18^{\text {th }}$ centuries.

\section{ASSAY SUBJECT}

\subsection{Commercial animal glue and replica samples}

Prior to the analysis of the replica and artifact samples, experiments were conducted on commercial and animal glue produced from cowhide to investigate the suitability of the selected antibody. Among the commercial animal glue, BP is an animal glue in powder form produced by the Japan Nakagawa Gofun Enogu company. It is the most frequently used animal glue as a painting binder and for preservation treatment. TTP is a powdered animal glue produced by the Japan Amanosan Cultural Heritages Research Institute that is produced using only cowhide and water. As an example of another commercial animal glue, we also selected the industrial adhesive Deok Young(KOR) animal glue(DIP) and GTP, produced using edible gelatin from Geltech(KOR). Both of these companies are domestic companies. The produced animal glue was made by the project team of the traditional technology materials bank, the Korea National University of Cultural Heritage, using only raw cowhide, salting treatment (30-36 months old yellow cattle- beef cattle) and water. The glue was produced for many different extraction temperatures, time and number of extractions(Korea National University of Cultural Heritage, 2018). To evaluate the possibility of detection for the case when the animal glue was mixed with pigment, animal glues of 3 different concentrations $(5.5 \%$, 
Table 1. Samples used for ELISA experiment

\begin{tabular}{|c|c|c|}
\hline Classification & Sample & Concentration $(\mathrm{mg} / 10 \mathrm{~mL})$ \\
\hline \multirow{4}{*}{ Commercial hide glue product } & $\mathrm{BP}$ & \multirow{10}{*}{$1,10,50$} \\
\hline & TTP & \\
\hline & DIP & \\
\hline & GTP & \\
\hline \multirow{6}{*}{ Produced hide glue product ${ }^{*}$} & TM81 & \\
\hline & TM82 & \\
\hline & TM83 & \\
\hline & TM91 & \\
\hline & TM92 & \\
\hline & TM93 & \\
\hline \multirow{9}{*}{ Replica of Dancheong $^{* *}$} & GGA1 & \multirow{9}{*}{10} \\
\hline & GGA2 & \\
\hline & GGA3 & \\
\hline & GGB1 & \\
\hline & GGB2 & \\
\hline & GGB3 & \\
\hline & GGC1 & \\
\hline & GGC2 & \\
\hline & GGC3 & \\
\hline
\end{tabular}

* Extraction conditions

TM81: $80^{\circ} \mathrm{C}, 20$ hours, 1 time / TM91: $90^{\circ} \mathrm{C}, 12$ hours, 1 time.

TM82: $80^{\circ} \mathrm{C}, 8$ hours, 2 times / TM92: $90^{\circ} \mathrm{C}, 8$ hours, 2 times.

TM83: $90^{\circ} \mathrm{C}, 8$ hours, 3 times / TM93: $100^{\circ} \mathrm{C}, 8$ hours, 2 times.

** Concentration of binder: A (5.5\%), B (7.7\%), C (9.1\%).

With UV ageing: 1 (None), 2 (after one week), 3 (after two weeks).

$7.7 \%, 9.1 \%$, weight ratio) were mixed with celadonite pigment to fabricate Noerok-additionally coated-replica samples. Degradation of the replica samples was performed for 14 days using a ultraviolet (UV) accelerated aging tester(QUV Accelerated Tester, Q-test, USA) with a Type 1A UV lamp(UVA-340 mm, $0.76 \mathrm{~W} / \mathrm{m}^{2}$ ) with reference to the Korean Industrial Standards (KS M ISO 16474-3 paint and varnish-exposure testing method using laboratory light source) to investigate the detection characteristics according to UV aging(Table 1).

\subsection{Dancheong samples}

The Dancheong sample to be analyzed consisted of 15 specimens in total. There were three categories of samples as follows: Dancheong of Daeungbojeon hall, the Naesosa temple in Buan estimated to be constructed in the $18^{\text {th }}$ century; Dancheong of Daeungjeon hall, the Tongdosa temple in Yangsan estimated to be constructed in the $17^{\text {th }}$ century;
Dancheong of Daeungjeon hall and Myeongbujeon hall, the Seonunsa temple in Gochang that was observed to have incorporated both the traditional and modern style of Dancheong(Figure 1 to 3). According to the previous studies using Py-GC/MS, pyrolytic compounds derived from protein-based binders were detected in the 11 types of Dancheong samples of the Naesosa and Tongdosa temples. In the case of the Dancheong samples of the Seonunsa temple, protein-based binders were identified in A and B samples but not from C and D samples(Yu, 2019).

According to Yeoamyugo, written by Kyung Jun Shin in the late Joseon dynasty, there is a record of the completion of Dancheong at the Naesosa temple, Daeungbojeon hall, in 1781. Since this period, several partial paint covering of Dancheong has taken place, but no records of large-scale construction related to Dancheong has been found. Therefore, Dancheong of Daeungbojeon hall in the Naesosa temple is estimated to be dated from the $18^{\text {th }}$ century Dancheong based 


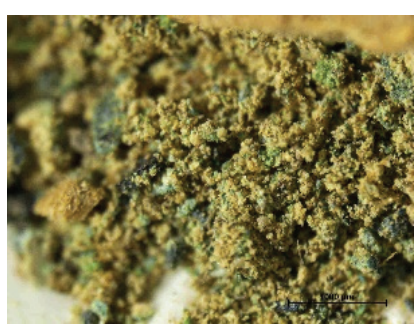

A. Celadonite

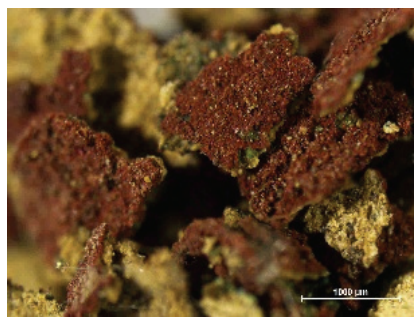

D. Red Ocher

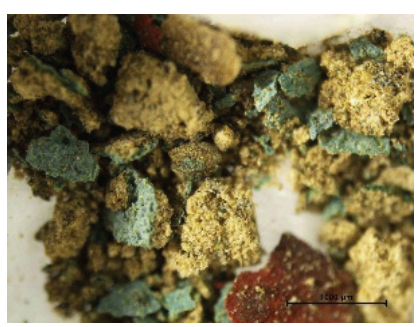

B. Celadonite

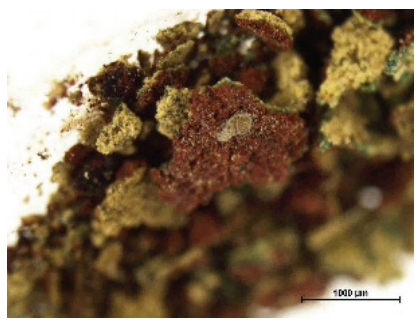

E. Red Ocher

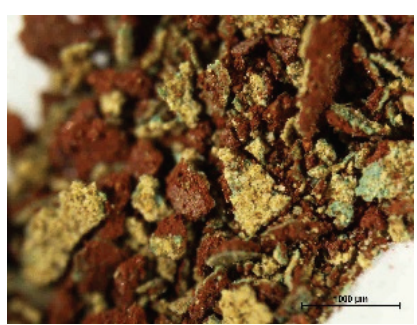

C. Red Ocher

Figure 1. Samples of Dancheong in Naesosa temple.

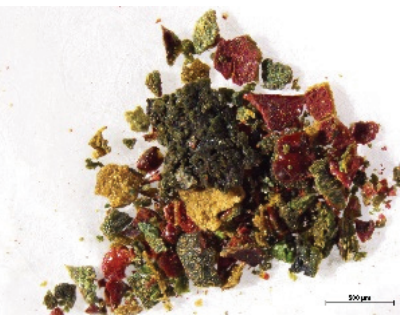

A. Cinnabar

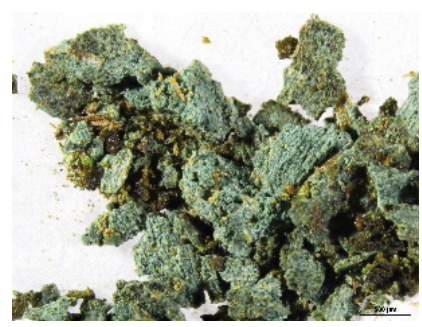

D. Celadonite

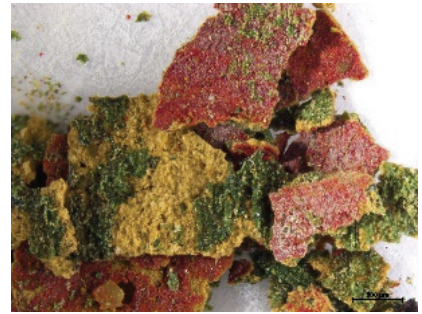

B. Cinnabar

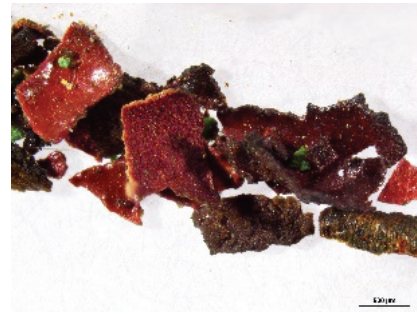

E. Cinnabar

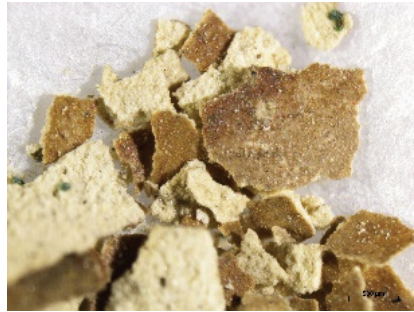

C. White pigment

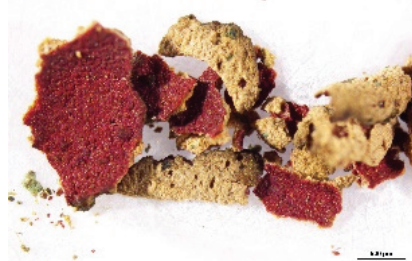

F. Cinnabar

Figure 2. Samples of Dancheong in Tongdosa temple.

on a literature review and the examination of patterns(Cultural Heritage Administration, 2016). Daeungjeon hall in Tongdosa temple was rebuilt in 1645 (the $23^{\text {rd }}$ year of King Injo's reign) after the Imjin War given that its foundation and numerous remains of Dancheongs at that time, currently exist. Dancheong patterns and techniques that belong to the period before the mid-Joseon dynasty(1700s) can be identified, and
Dancheong below the Gongpo part is thought to have been repainted later(Kim, 2012; Song, 2018). The Seonunsa temple was rebuilt after the Imjin War in 1614(the $5^{\text {th }}$ year of Gwanghaegun's reign). In 1689(the $15^{\text {th }}$ year of King Sukjong's reign) and 1840 (the $6^{\text {th }}$ year of King Hyeonjong's reign), the repair work and Dancheong work took place. In 1974, Dancheong construction and the partial paint covering of 


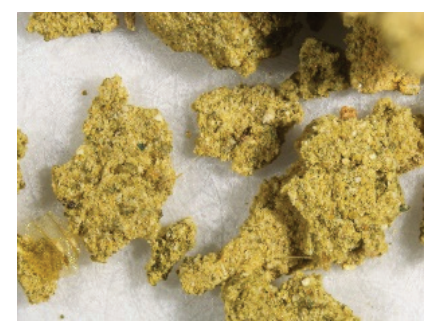

A. Celadonite

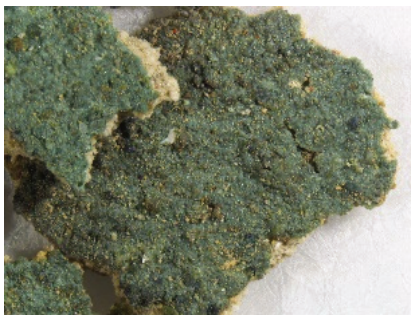

C. Celadonite

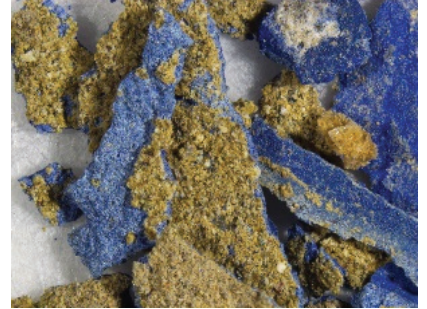

B. Ultramarine blue

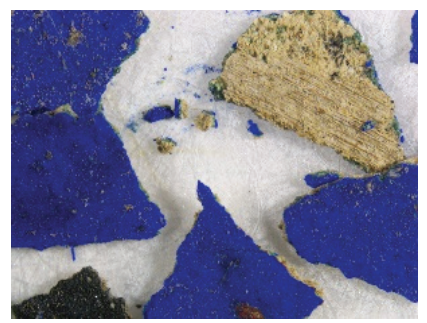

D. Ultramarine blue

Figure 3. Samples of Dancheong in Seonunsa temple.

Dancheong were completed. The old Dancheong, which is thought to have been painted in 1840 , is found in the members of a framework of beams and ceilings, and the patterns of the remaining members seem to have been repainted in 1974 (Cultural Heritage Administration, 2005).

\section{METHODS}

The antibody and experimental conditions were set by referring to the work of Mazurek et al. (2008). A volume of $100 \mu \mathrm{L}$ of the analyte and elution buffer was placed in a tube and eluted at room temperature. A volume of $200 \mu \mathrm{L}$ of $100 \mathrm{mM}$ sodium bicarbonate solution( $100 \mathrm{mM} \mathrm{NaHCO}{ }_{3}$, Sigma-Aldrich, USA) was added, mixed, and allowed to stand for 10 minutes. For the elution buffer, $5 \mathrm{~mL}$ of $1 \mathrm{M}$ tris-HCl(Merck Millipore, USA) and $1 \mathrm{~mL}$ of $0.5 \mathrm{M}$ EDTA(Ethylenediaminetetraacetic acid, Merck Millipore, USA) were mixed, $180 \mathrm{~g}$ of urea(Merck, USA) and $25 \mathrm{~mL}$ of $20 \%$ SDS solution(sodium dodecyl sulfate, Sigma, USA) were added and the total volume was adjusted to $500 \mathrm{~mL}$ with distilled water. The $\mathrm{pH}$ was adjusted to 7.4 with $\mathrm{NaOH}$ (Duksan Science, KOR). A volume of $65 \mu \mathrm{L}$ of sodium bicarbonate solution was added to a 96-well polystyrene plate for ELISA and $15 \mu \mathrm{L}$ of the sample elution buffer was added and the mixture was allowed to stand at $4^{\circ} \mathrm{C}$ for 24 hours. The solutions were washed twice each with $300 \mu \mathrm{L}$ of $\mathrm{PBS}$ (phosphate-buffered saline, Welgene, $\mathrm{KOR}$ ) and all the samples were tested in double numbers. Blocking buffer(Sea block buffer, Pierce Chemical, USA) diluted with a ratio 1:10 (v/v) was added to PBS and washed after 60 minutes. After the addition of $80 \mu \mathrm{L}$ of primary antibody(Collagen \#AB6577, Collagen \#34710, ABCAM, GBR), the solutions were left to stand at room temperature for 2 hours and then washed twice. A volume of $80 \mu \mathrm{L}$ of secondary antibody(Rabbit IgG \#AP132A, ABCAM, GBR) was added, left to stand at room temperature for 2 hours, and then washed three times. For color development, $80 \mu \mathrm{L}$ of pNPP solution(p-nitrophenyl phosphate, Merck Milipore, USA) was added. After checking to determine whether the reaction occurred in a blank well, $80 \mu \mathrm{L}$ of $0.75 \mathrm{M} \mathrm{NaOH}$ was added to terminate the reaction. The absorbance was measured twice at $405 \mathrm{~nm}$ using a microplate reader(VERSA max, Molecular Devices, USA) of MetaBio Co. Ltd, in Seoul. The absorbance threshold is the sum of the average absorbance $\left(\mathrm{A}_{\mathrm{av}}\right)$ and 3 times the standard deviation (3 SD) of the blanks for each antibody plate. It is thought to have a positive value when the absorbance of the analyte satisfies the absorbance threshold or higher. 


\section{CONCLUSION AND DISCUSSION}

\subsection{Commercial animal glue and replica sample}

The absorbance threshold was $0.03 \mathrm{OD}_{405}$. Moreover, a positive value of the absorbance was confirmed at all concentrations for the commercial and produced animal glue and the selected antibody was determined to be suitable for the analysis of animal glue. The absorbance of $0.5 \%$ concentration $(50 \mathrm{mg} / 10 \mathrm{~mL})$ of edible gelatin(GTP2) and the commercial animal glue(TTP1) made from only water and cowhide was the highest, and the absorbance of the remaining 6 types of commercial and produced animal glue did not show significant differences. As the concentration increased, a general increase of the absorbance was confirmed, but the increase was not proportional to the concentration(Table 3, Figure 4). It was also determined that the replica samples exhibited higher values compared to the absorbance threshold value for all concentrations and UV aging samples. This confirmed that the animal glue mixed with the celadonite pigment was analyzed. There was no difference in the absorbance for variation of the animal glue concentration and UV aging(Table 4, Figure 5). Therefore, in the case of commercial animal glue and the replica samples, $1 \mathrm{mg}$ of animal glue can be detected using ELISA.

Table 3. ELISA optical density for commercial and produced animal glue from cowhide

\begin{tabular}{|c|c|c|c|c|}
\hline \multirow{2}{*}{ Sample } & & \multirow{2}{*}{$\begin{array}{c}\text { Concentration } \\
(\mathrm{mg} / 10 \mathrm{~mL})\end{array}$} & \multicolumn{2}{|c|}{$\mathrm{OD}_{405 \mathrm{~nm}} \pm \mathrm{SD}$} \\
\hline & & & Collagen antibody 1 & Result \\
\hline \multirow{12}{*}{ Commercial animal glue } & \multirow{3}{*}{$\mathrm{BP}$} & 1 & $0.15 \pm 0.01$ & + \\
\hline & & 10 & $0.25 \pm 0.01$ & + \\
\hline & & 50 & $0.30 \pm 0.06$ & + \\
\hline & \multirow{3}{*}{ TTP1 } & 1 & $0.17 \pm 0$ & + \\
\hline & & 10 & $0.39 \pm 0.06$ & + \\
\hline & & 50 & $0.63 \pm 0.07$ & + \\
\hline & \multirow{3}{*}{ DIP } & 1 & $0.13 \pm 0$ & + \\
\hline & & 10 & $0.21 \pm 0$ & + \\
\hline & & 50 & $0.42 \pm 0.04$ & + \\
\hline & \multirow{3}{*}{ GTP2 } & 1 & $0.12 \pm 0.01$ & + \\
\hline & & 10 & $0.26 \pm 0$ & + \\
\hline & & 50 & $0.70 \pm 0.04$ & + \\
\hline \multirow{18}{*}{ Produced animal glue } & \multirow{3}{*}{ TM81 } & 1 & $0.17 \pm 0$ & + \\
\hline & & 10 & $0.34 \pm 0.01$ & + \\
\hline & & 50 & $0.43 \pm 0.02$ & + \\
\hline & \multirow{3}{*}{ TM82 } & 1 & $0.15 \pm 0.01$ & + \\
\hline & & 10 & $0.33 \pm 0.02$ & + \\
\hline & & 50 & $0.45 \pm 0.01$ & + \\
\hline & \multirow{3}{*}{ TM83 } & 1 & $0.11 \pm 0.02$ & + \\
\hline & & 10 & $0.31 \pm 0.06$ & + \\
\hline & & 50 & $0.45 \pm 0.08$ & + \\
\hline & \multirow{3}{*}{ TM91 } & 1 & $0.20 \pm 0.01$ & + \\
\hline & & 10 & $0.04 \pm 0.02$ & + \\
\hline & & 50 & $0.53 \pm 0.05$ & + \\
\hline & \multirow{3}{*}{ TM92 } & 1 & $0.18 \pm 0$ & + \\
\hline & & 10 & $0.31 \pm 0.03$ & + \\
\hline & & 50 & $0.51 \pm 0.01$ & + \\
\hline & \multirow{3}{*}{ TM93 } & 1 & $0.10 \pm 0$ & + \\
\hline & & 10 & $0.27 \pm 0.03$ & + \\
\hline & & 50 & $0.44 \pm 0.02$ & + \\
\hline Abso & threshold & & $>0.03$ & \\
\hline
\end{tabular}




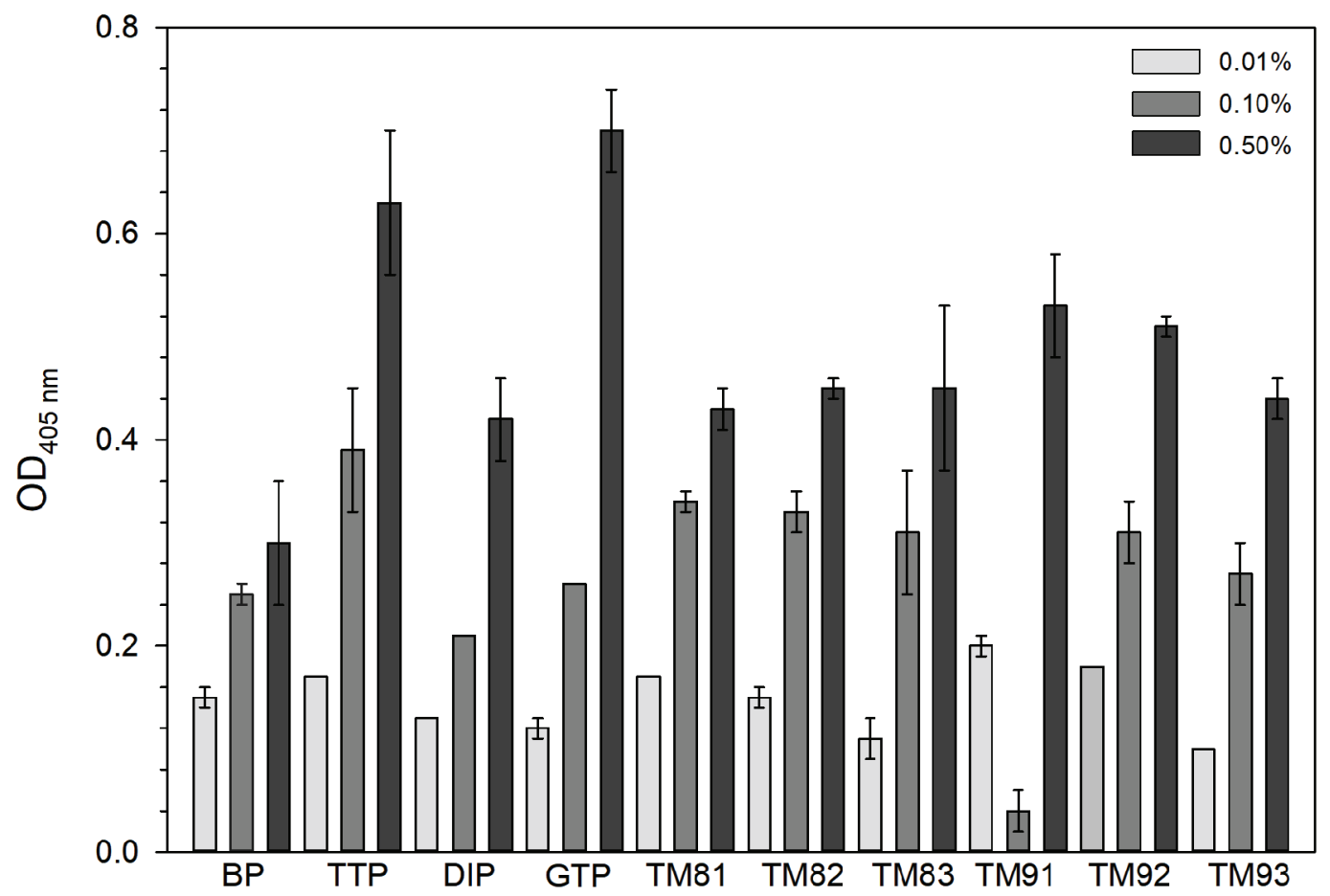

Figure 4. ELISA optical density of animal glue from cowhide according to concentration.

Table 4. ELISA optical density of painting layer of replica samples

\begin{tabular}{|c|c|c|c|}
\hline & \multirow{2}{*}{ Sample } & \multicolumn{2}{|c|}{$\mathrm{OD}_{405 \mathrm{~nm}} \pm \mathrm{SD}$} \\
\hline & & Collagen antibody 1 & Result \\
\hline \multirow{3}{*}{ GGA } & Before degradation & $0.66 \pm 0.05$ & + \\
\hline & After degradation for 1 week & $0.56 \pm 0$ & + \\
\hline & After degradation for 2 weeks & $0.63 \pm 0.02$ & + \\
\hline \multirow{3}{*}{ GGB } & Before degradation & $0.53 \pm 0.03$ & + \\
\hline & After degradation for 1 week & $0.53 \pm 0.05$ & + \\
\hline & After degradation for 2 weeks & $0.68 \pm 0.02$ & + \\
\hline \multirow{4}{*}{ GGC } & Before degradation & $0.63 \pm 0.02$ & + \\
\hline & After degradation for 1 week & $0.68 \pm 0.02$ & + \\
\hline & After degradation for 2 weeks & $0.46 \pm 0.01$ & + \\
\hline & Absorbance threshold & $>0.06$ & \\
\hline
\end{tabular}




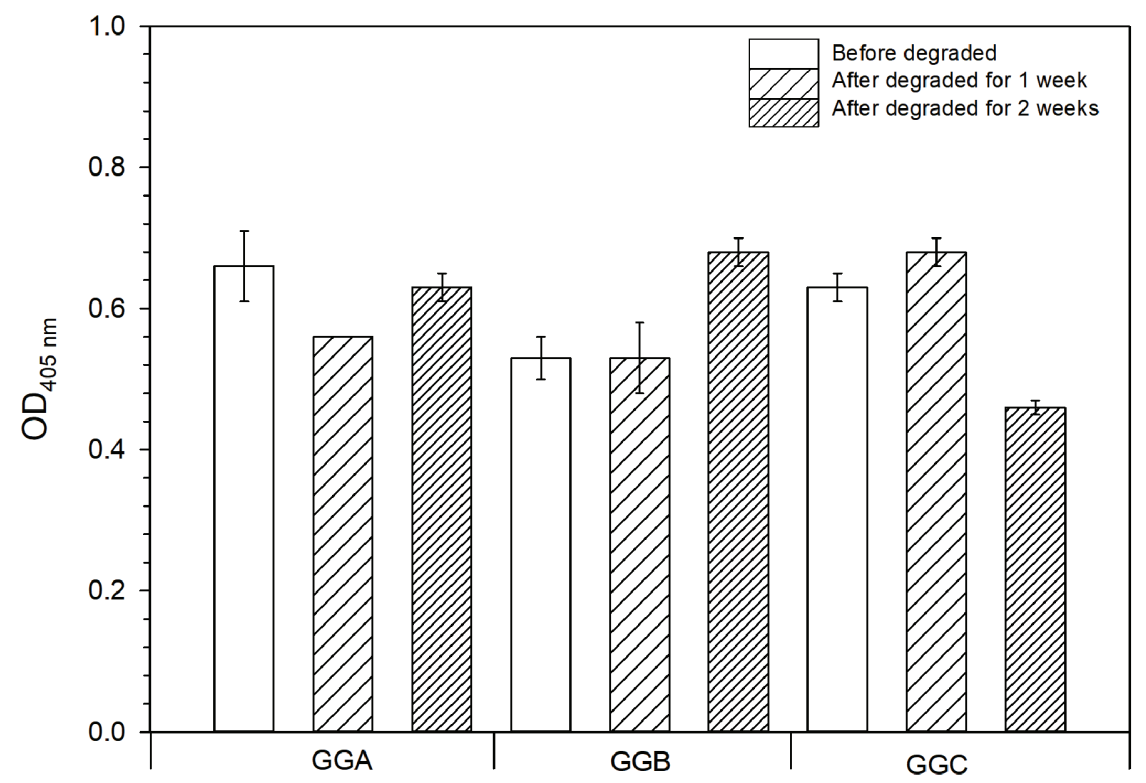

Figure 5. ELISA optical density for painting layer of replica samples according to degradation.

\subsection{Dancheong sample}

Analysis of the control group, the Japanese animal glue (BP) and replica sample(GGC) revealed the absorbance. Given that collagen antibody 2 was observed with an absorbance of approximately 3-6 times higher, two primary antibodies were selected for the experiment to analyze the Dancheong sample. By applying the identified antibody using the animal glue and replica sample, and the experimental procedure to the Dancheong sample, given that the absorbance of the Dancheong sample of Naesosa and Seonunsa was in the range of $0.08-0.10 \mathrm{OD}_{405}$ and the absorbance threshold was 0.11 $\mathrm{OD}_{405}$, collagen antibody 1 had negative values. However, given that the difference for the absorbance threshold was very small at $0.01 \mathrm{OD}_{405}$, we are of the opinion that if there is a greater emphasis on preventing the contamination of the blank or if more samples are available, it may be possible to detect animal glue. In the case of collagen antibody 2, animal glue was detected in the 4 types of Tongdosa samples of A, B, E, and $\mathrm{F}$. When the amount of the sample was compared for the 4 types of samples for which animal glue was detected, the absorbance was determined to be proportional to the amount of sample(Table 5, Figure 6). Therefore, given the higher reactivity of collagen antibody 2 , the results indicate that this antibody is suitable for use in the detection of animal glue.

Differences in the absorbance were observed depending on the type of pigment. Celadonite and red ocher(Naesosa temple), celadonite and white pigment(Tongdosa temple), celadonite and ultramarine blue pigment(Seonunsa temple) and all four Tongdosa temple Dancheong samples were red pigments(Song, 2018). It is presumed that the amount of binder used in painting varies depending on the type of pigment given that the oil absorption of the pigment varies according to the particle size and shape of the pigment (Shinhanart, 1999). In addition, previous studies on the effect of pigment metal ions on casein binder have shown that metal ions of calcium, iron and copper-based pigments promote protein denaturation(Ren et al., 2015). This indicates that iron and copper components in the pigment promote degradation of the protein, which modifies the epitope and paratope of the protein, resulting in low absorbance(Cartechini et al., 2010).

\section{CONCLUSION}

In this study, it was confirmed that ELISA can be used for the identification of animal glue, given that it was successfully detected in Japanese powdered animal glue, produced animal glue with various extraction conditions and replica samples mixed with pigments using ELISA method. This study is the first reported attempt to analyze animal glue, the binder in the Dancheong sample of the $17^{\text {th }}$ and $18^{\text {th }}$ Century Joseon 
Table 5. ELISA optical density for painting layer of Dancheong samples from temples

\begin{tabular}{|c|c|c|c|c|c|}
\hline & \multirow{2}{*}{ Samples } & \multicolumn{4}{|c|}{ Absorbance $\left(\mathrm{OD}_{405 \mathrm{~nm}} \pm \mathrm{SD}\right)$} \\
\hline & & Collagen antibody 1 & Result & Collagen antibody 2 & Result \\
\hline \multirow{5}{*}{$\begin{array}{l}\text { Naesosa } \\
\text { temple }\end{array}$} & $\mathrm{A}(1.20 \mathrm{mg})$ & $0.08 \pm 0$ & - & $0.13 \pm 0.01$ & - \\
\hline & $\mathrm{B}(0.71 \mathrm{mg})$ & $0.09 \pm 0.01$ & - & $0.14 \pm 0.01$ & - \\
\hline & $\mathrm{C}(0.81 \mathrm{mg})$ & $0.09 \pm 0$ & - & $0.14 \pm 0$ & - \\
\hline & $\mathrm{D}(1.08 \mathrm{mg})$ & $0.10 \pm 0.01$ & - & $0.19 \pm 0.02$ & - \\
\hline & $\mathrm{E}(0.37 \mathrm{mg})$ & $0.08 \pm 0$ & - & $0.13 \pm 0$ & - \\
\hline \multirow{6}{*}{$\begin{array}{l}\text { Tongdosa } \\
\text { temple }\end{array}$} & A $(0.18 \mathrm{mg})$ & $0.10 \pm 0$ & - & $0.38 \pm 0.08$ & + \\
\hline & B (0.49 mg) & $0.09 \pm 0$ & - & $0.45 \pm 0.19$ & + \\
\hline & $\mathrm{C}(0.46 \mathrm{mg})$ & $0.08 \pm 0$ & - & $0.11 \pm 0$ & - \\
\hline & $\mathrm{D}(0.79 \mathrm{mg})$ & $0.08 \pm 0$ & - & $0.11 \pm 0.01$ & - \\
\hline & $\mathrm{E}(0.51 \mathrm{mg})$ & $0.09 \pm 0.01$ & - & $0.58 \pm 0.13$ & + \\
\hline & $\mathrm{F}(0.61 \mathrm{mg})$ & $0.14 \pm 0.01$ & + & $0.73 \pm 0.03$ & + \\
\hline \multirow{4}{*}{$\begin{array}{l}\text { Seonunsa } \\
\text { temple }\end{array}$} & $\mathrm{A}(1.18 \mathrm{mg})$ & $0.08 \pm 0$ & - & $0.12 \pm 0$ & - \\
\hline & $\mathrm{B}(1.05 \mathrm{mg})$ & $0.08 \pm 0$ & - & $0.11 \pm 0$ & - \\
\hline & $\mathrm{C}(0.73 \mathrm{mg})$ & $0.09 \pm 0$ & - & $0.11 \pm 0$ & - \\
\hline & $\mathrm{D}(0.38 \mathrm{mg})$ & $0.08 \pm 0$ & - & $0.19 \pm 0.03$ & - \\
\hline $\begin{array}{l}\text { Commercial } \\
\text { animal glue }\end{array}$ & BP (1.55 mg) & $0.32 \pm 0$ & + & $0.9 \pm 0.02$ & + \\
\hline $\begin{array}{l}\text { Replica } \\
\text { sample }\end{array}$ & GGC $(0.25 \mathrm{mg})$ & $0.37 \pm 0.04$ & + & $2.12 \pm 0.11$ & + \\
\hline \multicolumn{2}{|c|}{ Absorbance threshold } & $>0.11$ & & $<0.37$ & \\
\hline
\end{tabular}

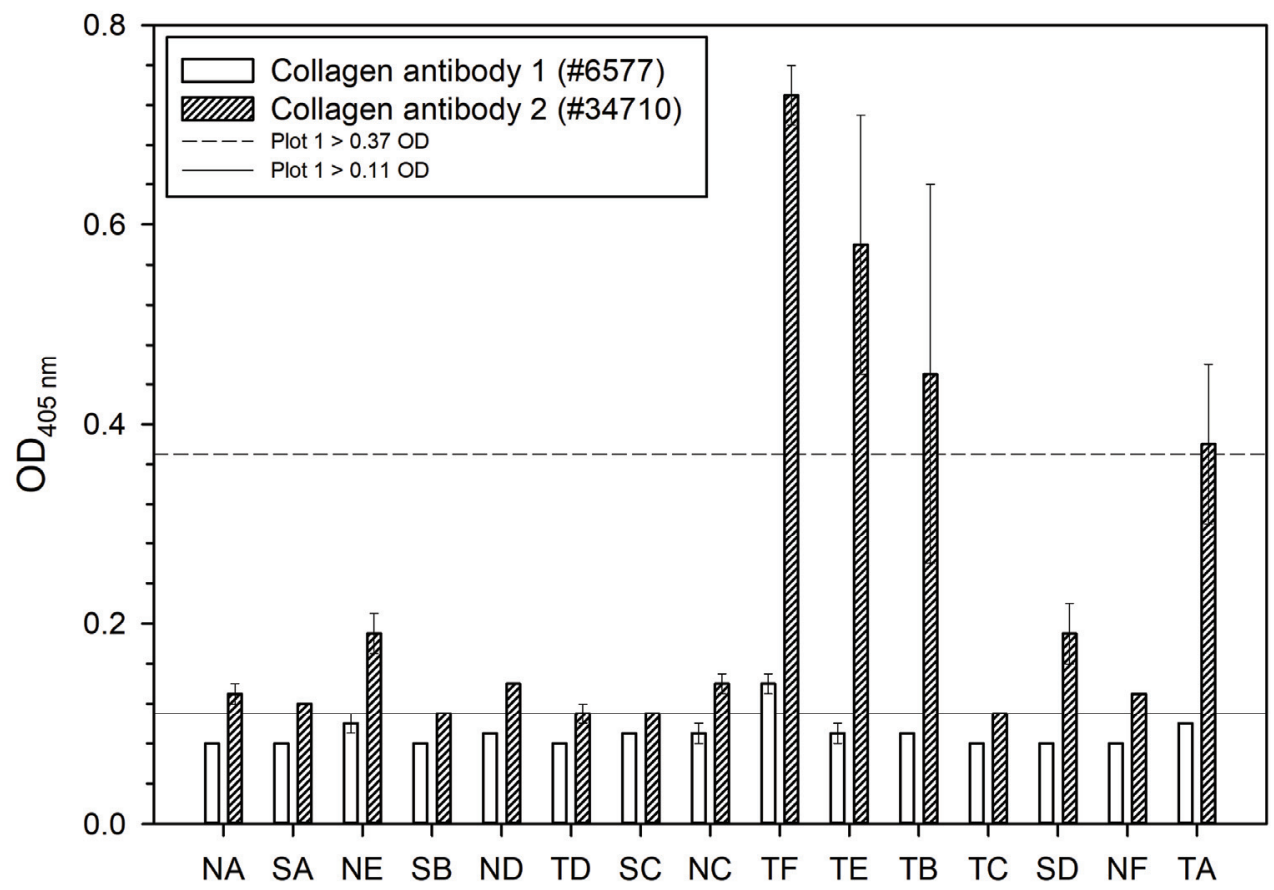

Figure 6. ELISA optical density in descending order by weight of Dancheong samples. 
dynasty, in which ELISA was proposed as one of the binder assay methods. It is thought that quantitative analysis of proteins that have not been confirmed in this study will be needed for more reliable analysis. In particular, further studies with an emphasis on the effects of Korean traditional pigments on the denaturation of protein binder is necessary. It is expected that a comprehensive understanding of the traditional Dancheong technique will be achieved by analyzing Dancheong patterns, pigments and the various binders that have been used in the past.

In addition, it is expected that based on the analysis of binders in various painted cultural properties as well as Dancheong, a more complete understanding of traditional painting techniques will be achieved.

\section{REFERENCES}

Colombini, M.P. and Modugno, F., 2004, Characterisation of proteinaceous binders in artistic paintings by chromatographic techniques. Journal of Separation Science, 27(3), 147-160.

Cultural Heritage Administration, 2005, Seonunsa Daesoongjeon: actual survey report. 57-63. (in Korean)

Cultural Heritage Administration, 2016, Naesosa Daewoongbojeon dancheong: Pattern survey and copy. 41-54. (in Korean)

Hu, W., Zhang, H. and Zhang, B., 2015, Identification of organic binders in ancient Chinese paintings by immunological techniques. Microscopy and Microanalysis, 21(5), 1278-1287.

Kim, H.J., 2012, Understanding of Korean dancheong. Hantee Media, Seoul, 246-247. (in Korean)

Kim, S.K., Han, M.S., Jeong, S.H. and Kim, M.J., 2014, Study on the restored Sungnyemun Gate dancheong. Journal of Conservation Science, 30(4), 447-456. (in Korean with English abstract)
Koo, U.H., 2016, An experimental study for the reproduction of the dancheong technique for royal palaces since the $17^{\text {th }}$ Century. Ph.D. dissertation, Myongji University, Yongin, 58-64. (in Korean with English abstract)

Korea National University of Cultural Heritage, 2018, Study on the manufacturing techniques and characteristics of traditional animal glue. 198-267. (in Korean)

Mazurek, J., Schilling, M., Chiari, G. and Heginbotham, A., 2008, Antibody assay to characterize binding media in paint. ICOM Committee for Conservation, New Delhi, September 22-26, 849-856.

Shinhanart, 1999, The science of colour paint(Han, B.L., Hwang, I.S. and Park, Y.B., trans.). Yekyung, Seoul, 26-27. (Original work published in 1994) (in Korean)

Song, Y.N, 2018, Materials characteristics of pigments on dancheong in Joseon dynasty. Ph.D. dissertation, Kongju University, Gongju, 126. (in Korean with English abstract)

Park, J.S., 2015, Analysis of animal glue by pyrolysis/GC/MS. Analytical Science \& Technology, 28(3), 221-227. (in Korean with English abstract)

Park, J.S., Kim, M.J. and Kim, S.K., 2016, Confirming animal glue in dancheong sample by pyrolysis/GC/MS. Journal of Conservation Science, 32(1), 21-32. (in Korean with English abstract)

Ren, F., Atlasevich, N., Baade, B., Loike, J. and Arslanoglu, J., 2016, Influence of pigments and protein aging on protein identification in historically representative casein-based paints using enzyme-linked immunosorvent assay. Analytical and Bioanalytical Chemistry, 408(1), 203-215.

Yu, J.A., 2019, Analysis of binder in Korean traditional dancheong. Ph.D. dissertation, Korea National University of Cultural Heritage, Buyeo, 142-158. (in Korean with English abstract) 